Pobrane z czasopisma Annales H - Oeconomia http://oeconomia.annales.umcs.pl Data: 26/04/2023 10:59:36

DOI:10.17951/h.2017.51.3.161

\begin{tabular}{lcl}
\hline \multicolumn{1}{c}{ A N N A L E S } \\
UNIVERSITATIS MARIAE CURIE-SKŁODOWSKA \\
LUBLIN - POLONIA \\
VOL. LI, 3 & SECTIO H \\
\hline
\end{tabular}

Maria Curie-Skłodowska University in Lublin, Department of Human Resources Management

PAWEŁ WÓJCIK

pawel.wojcik@poczta.umcs.lublin.pl

\title{
Empowerment in Modern Organizations - Determinants and Benefits
}

Uwarunkowania i korzyści empowermentu we współczesnych organizacjach

Keywords: empowerment; employees' efficiency; human resources management; decision-making process

Słowa kluczowe: empowerment; efektywność pracowników; zarządzanie zasobami ludzkimi; proces podejmowania decyzji

JEL code: M10; M12; M51

\section{Introduction}

At present, the traditional management model based upon strict control does not prove itself in practice. Significant requirements posed by clients, novel technologies, and growing globalization, result in traditional, hierarchical organizational structures based upon command and control, becoming less valid. Instead, employees must exhibit initiative, be creative, and embrace responsibility for their actions. The new role obliges them to become partners of their superiors [Blanchard 2007, p. 90].

According to Kieżun [as cited in: Grajewski 2003, pp. 55-56], organizations of the $21^{\text {st }}$ century require a different approach than the hitherto one, both with regard to management, and development of relations within organizations. A modern organization must rely upon swift, independent, and responsible actions of its employees. Blanchard [2007, p. 89] is of similar opinion. The author observes that leadership 
based upon traditional organizational hierarchy evolves towards individuals being capable of independent thinking and action.

Effective management exhibited by modern managers revolves around discovering and applying a potential hidden within employees: ability to think and innovate, desire for self-development and participation in decision making, and embracing responsibility. Taking employees' needs into consideration, rather than disregarding them, has become a widespread norm. Managers ought to surround themselves with people instead of attempting to control them [Otto 2004, pp. 173-174]. The "push" strategy, denoting managers' convincing employees to react in a particular manner, ought to be replaced by the "pull" approach [Whetten and Cameron 2011, p. 443].

Due to challenges experienced by enterprises, towards the end of the 1980s and at the beginning of the 1990s, when both practitioners and theoreticians commenced a search for ways of improving commitment and autonomy and engagement of employees in decision-making processes, a radical change from the traditional organizational structure and managers' roles occurred [Hammuda and Dulaimi 1997, p. 290]. The idea of empowerment emerged on the basis of these considerations.

Bridging the gap between managers and employees by the growth of knowledge and responsibility, and development of organizational commitment, constitute the main objective of employees' empowerment [Hanaysha and Tahir 2016, p. 274]. According to Lawler, Mohrman and Benson [as cited in: Spreitzer 2007, p. 54], more than $70 \%$ of organizations introduced elements of empowerment with regard to their employees. Empowerment constitutes a fundamental, primary and superior source of success and development of any enterprise with regard to a boost of productivity [Akbar et al. 2011, p. 680]. Therefore, empowerment was offered as the most effective solution in numerous businesses, including customer service [Bowen, Lawler as cited in: Hocutt and Stone 1998, p. 119].

\section{Empowerment - definitions}

With reference to employees, the term "empowerment" became popular in the 1980 s and the 1990s, along with the development of the idea of human resources management (HRM) and total quality management (TQM) [Wilkinson 1998, p. 40]. However, the origin of the term may be traced back to Taylorism [Jo and Park 2016, p. 391]. In addition, the roots of the term may be seen in psychology, sociology and theology [Whetten and Cameron 2011, p. 446].

Empowerment is frequently understood as knowledge-sharing, improvement of intellectual abilities, and autonomy in decision-making [Karim and Rehman and 2012, p. 96]. However, some researchers suggest to perceive it as a motivating factor, rather than mere delegation [Conger and Kanungo 1988, p. 474].

Employees' empowerment is perceived as a motivational practice aiming to boost efficiency by facilitating opportunities for participating and engaging in de- 
cision-making. It is associated primarily with the development of trust, motivation, participation in decision-making, and bridging gaps between employees and top management [Meyerson and Dewettinck 2012, p. 40]. Conger and Kanungo [1988, p. 474] present similar views. They define empowerment as "a process of enhancing feelings of self-efficacy among organizational members through the identification of conditions that foster powerlessness and through their removal by both formal organizational practices and informal techniques of providing efficacy information".

Whetten and Cameron [2011, p. 443] observe that empowerment constitutes a managerial skill which must be developed. According to researchers, it denotes enabling and assistance in growth of self-confidence, overcoming powerlessness and helplessness, fostering decision-making, and stimulating employees' internal motivation to complete work tasks.

The introduction of empowerment does not denote independent thinking and actions, doing what one feels like, and making critical decisions regarding work, but embracing co-responsibility and risks associated with results and consequences of these decisions [Blanchard 2007, p. 58].

\section{Psychological and organizational empowerment}

Empowerment constitutes a phenomenon examined from the point of view of organizations as a whole, and from the standpoint of employees.

Spreitzer [as cited in: Ebers and Maurer 2014, p. 321] identified two approaches to empowerment:

- psychological empowerment - pertains to individual perceptions of empowerment. These consist of employees' views or attitudes towards their work and role in the organization;

- organizational empowerment, also termed relational empowerment, and social-structural empowerment. It refers to structures, policies, and practices present in the organization, thus, pertains to conditions facilitating the emergence of empowerment or lack of thereof.

Quinn and Spreitzer [1997, p. 41] indicated four features manifested by empowered employees. The characteristics constitute four elements of psychological empowerment:

- empowered employees manifest a sense of self-determination, i.e. they have a choice of how they conduct their work;

- empowered employees manifest a sense of meaning, i.e. they feel that work they carry out is meaningful, and they care for what they do;

- empowered employees manifest a sense of competence, i.e. they believe they possess skills necessary to conduct their work well, and they are convinced they can do it; 
- empowered employees manifest a sense of impact, i.e. they believe they can influence a department or a unit they work in, and that others take their ideas into consideration.

On the other hand, Whetten and Cameron [2011, pp. 447-451] enumerate the following as belonging to psychological empowerment:

- self-efficacy;

- self-determination;

- personal consequence;

- meaning;

- trust.

From the point of view of individuals, empowerment constitutes a perception of being empowered, and the state of being empowered constitutes a cognitive and subjective experience of an individual [Conger and Kanungo 1988, p. 473]. Therefore, the fact that not every employee can be empowered ought to be highlighted. Employees' individual characteristics ought to be considered in any case [Özarallı 2015, p. 367].

For researchers representing the individual approach, organizational factors merely constitute elements enabling employees' empowerment [Marzec 2014, p. 46]. As a consequence, organizational empowerment is defined as "a practice, or set of practices involving the delegation of responsibility down the hierarchy so as to give employees increased decision-making authority in respect of the execution of their primary work tasks" [Leach, Wall and Jackson 2003, p. 28].

Lautizi, Laschinger and Ravazzolo [as cited in: Yang et al. 2014, p. 187] observe that organizational empowerment constitutes the center of work environment and includes organizational strategies for individual units with empowered environment, and enables individuals to conduct their work effectively. Organizational empowerment determines psychological empowerment [Chang, Shih and Lin 2010, p. 428]. Whetten and Cameron [2011, p. 445] are of similar opinion. They observe that an employee cannot be empowered. However, conditions enabling them to empower themselves can be created.

Spreitzer [as cited in: Ebers and Maurer 2014, p. 321] indicated 5 elements of organizational empowerment:

- participating in decision-making;

- skill/knowledge-based pay;

- open flow of information;

- flat organizational structure;

- training.

According to Kanter [as cited in: Yang et al. 2014, p. 187], organizational empowerment's structure emerges from four sources:

- access to information - denotes that employees have the opportunity to become familiar with decisions made in the organization, its policies, stored data, and objectives. At the same time, employees ought to possess technical 
knowledge and experience enabling them to work effectively in their workplaces;

- receiving support - emerges when employees of all grades receive feedback from their superiors, subordinates and equivalents, which is synonymous with receiving support;

- the ability to mobilize resources - access to resources refers to one's ability to gain finances, materials, time and facilities, necessary to complete a job and achieve organizational objectives;

- the structure of opportunity - access to opportunities refers to work conditions which lead to improved learning, challenges, knowledge, and skills critical for employees' development.

Organizational empowerment is responsible for developing conditions for the emergence of psychological empowerment. Therefore, it constitutes a vital element of organizational culture [Chu 2003, p. 508]. According to Blanchard [2007, pp. 63-73], a drive towards empowerment requires strong leadership who must aspire to a cultural change towards empowerment culture (Table 1).

Table 1. Comparison of hierarchical and empowerment cultures

\begin{tabular}{|l|l|}
\hline \multicolumn{1}{|c|}{ Hierarchical culture } & \multicolumn{1}{c|}{ Empowerment culture } \\
\hline planning & visionary approach \\
\hline command and control & cooperation to achieve results \\
\hline monitoring & self-monitoring \\
\hline individual relations & team responsibility \\
\hline pyramid structure & cross-functional structure \\
\hline cognitive processes & projects \\
\hline managers & trainers/team leaders \\
\hline employees & team members \\
\hline participatory management & self-management teams \\
\hline do as you are told & you are responsible for your work \\
\hline submission & own view of the situation \\
\hline
\end{tabular}

Source: Blanchard [2007, p. 62].

Due to the fact that organizational and psychological elements overlap, factors facilitating and hindering employees' empowerment are worth examining (Table 2).

Table 2. Conditions facilitating employees' empowerment

\begin{tabular}{|l|l|l|}
\hline \multicolumn{1}{|c|}{ State of an organization } & \multicolumn{1}{|c|}{ Unfavorable conditions } & \multicolumn{1}{c|}{ Favorable conditions } \\
\hline Organizational structure & High centralization, formalization & Decentralization, low formalization \\
\hline Competitive strategy & $\begin{array}{l}\text { Low costs and standards of products } \\
\text { and services }\end{array}$ & $\begin{array}{l}\text { Customer orientation, high differentia- } \\
\text { tion of products and services }\end{array}$ \\
\hline Tasks and technology & $\begin{array}{l}\text { Single, repetitive tasks and reliable } \\
\text { technology }\end{array}$ & $\begin{array}{l}\text { Complex, routine-free tasks, openness to } \\
\text { new technologies }\end{array}$ \\
\hline Customer relations & $\begin{array}{l}\text { Short transactions in short periods of } \\
\text { time }\end{array}$ & $\begin{array}{l}\text { Repetitive transactions, continuation of } \\
\text { cooperation }\end{array}$ \\
\hline
\end{tabular}


Pobrane z czasopisma Annales H - Oeconomia http://oeconomia.annales.umcs.pl

Data: 26/04/2023 10:59:36

166

PAWEL WÓJCIK

\begin{tabular}{|l|l|l|}
\hline State of an organization & \multicolumn{1}{|c|}{ Unfavorable conditions } & \multicolumn{1}{c|}{ Favorable conditions } \\
\hline Corporate culture & $\begin{array}{l}\text { Reliability, effectiveness of operating } \\
\text { without mistakes }\end{array}$ & Flexibility, learning, participation \\
\hline Features of employees & $\begin{array}{l}\text { Low motivation, external control, } \\
\text { emotional instability }\end{array}$ & $\begin{array}{l}\text { High need for achievement, internal } \\
\text { control, emotional stability }\end{array}$ \\
\hline Abilities of employees & Low abilities, lack of experience & High, professional abilities \\
\hline Forms of employment & Temporary employment & Steady, long-term employment \\
\hline $\begin{array}{l}\text { Employees ownership, } \\
\text { profit-sharing }\end{array}$ & None or very small & $\begin{array}{l}\text { Employees are stakeholders or co-own- } \\
\text { ers }\end{array}$ \\
\hline $\begin{array}{l}\text { Programs of employee } \\
\text { involvement }\end{array}$ & None & $\begin{array}{l}\text { Costly programs strongly supported by } \\
\text { top management }\end{array}$ \\
\hline Mutual trust & Low & High \\
\hline
\end{tabular}

Source: Yukl [2007, p. 161].

\section{Empowerment - costs and benefits}

Wellins, Byham and Wilson [as cited in: Hanaysha 2016a, p. 229] observe that organizations cherishing high empowerment of their employees will have a greater capacity for ensuring long-term survival and coping with challenges. Empowerment solves the eternal problem of Taylorism and bureaucratic workplaces whose creativity is diminished and employees alienated [Wilkinson 1998, p. 40].

Undeniably, the introduction of empowerment into organizations entails a certain dilemma. On the one hand, studies indicate that empowered employees are more productive, satisfied, innovative, thus are able to develop high-quality products and services, as opposed to their non-empowered colleagues. On the other hand, empowerment denotes less control and grants decision-making powers to others, enables them to set objectives, achieve results and obtain rewards [Whetten and Cameron 2011, p. 443]. Therefore, costs and benefits of empowerment are worth examining.

Based on the review of literature, Sahoo and Das [2011, p. 47] indicated the most vital benefits resulting from the introduction of empowerment:

- growth of trust and commitment among employees;

- stimulation of motivation for limiting errors and taking more responsibility for one's actions;

- enabling employees to express their beliefs and new ideas with regard to daily tasks;

- participation in permanent improvement of processes, products and services;

- fostering employees' loyalty, reduction of turnover, absences and sicknesses;

- improvement of productivity as a result of the growth of pride, self-respect and self-esteem;

- applying peer pressure and self-management teams to oversee employees and their productivity;

- limiting waste, and improving quality as a result of responding to clients' needs;

- maintaining and developing competitiveness; 
- fostering trust and cooperation with superiors;

- fostering communication among employees and among various departments within the organization;

- enabling employees to identify and solve problems, thus, allowing them to improve their work;

- improving organizational commitment and organizational effectiveness;

- developing a healthy organizational climate and culture.

On the other hand, in order to benefit, an organization must incur certain costs originating from the introduction of empowerment. These costs encompass [Potoczek 2010, pp. 42-51]:

- greater costs of trainings;

- greater costs of employment of qualified staff;

- costs associated with varied quality of services offered by employees;

- costs associated with the lack of sense of equal treatment of clients;

- costs associated with problems solved and wrong decisions made by employees;

- costs of conflicts among middle-management resulting from the feeling of being threatened.

\section{Empowerment - impact on work results}

Empowerment constitutes a phenomenon frequently examined by researchers worldwide in the context of numerous sectors and branches. Studies encompass employees on various levels in organizations' hierarchy, and clients of these organizations as well. Studies pertain to the direct and indirect impact of empowerment on the organization.

International studies proved that representative companies worldwide (including the USA, the UK, France, Japan, Korea, South America) observe benefits resulting from employees' empowerment which enable them to improve competitiveness on the market [Sparoow et al. as cited in: Robbins, Crino, and Fredendall 2002, p. 438]. In addition, numerous analyses indicate that empowerment constituted a cornerstone of changes in management aiming at achieving quality. In the 1990s, it constituted the key to competitiveness and successes of companies [Chu 2003, p. 506].

Quinn and Spreitzer [1997, p. 42] indicated that empowered middle managers differ considerably from their non-empowered colleagues. The differences are the following:

- empowered employees perceive themselves as more effective at work. Moreover, they are viewed as more effective by their colleagues;

- empowered employees perceive themselves as more innovative and do not fear when attempting something new. In addition, their superiors and subordinates share the view; 
Pobrane z czasopisma Annales H - Oeconomia http://oeconomia.annales.umcs.pl

Data: 26/04/2023 10:59:36

- leadership skills of empowered employees evolve. They direct their interest upwards and stimulate change;

- their colleagues perceive them as charismatic, which enables them to introduce significant changes in organizations.

Ripley and Ripley [as cited in: Hanaysha 2016a, p. 300] indicated that empowerment may result in the growth of motivation of employees conducting routine work, improve their job satisfaction, boost loyalty and productivity, and reduce turnover. Lan and Chong [2015, p. 184] acknowledged the significant relationship between empowerment and employees' attitude towards work.

The impact of empowerment on job satisfaction was acknowledged in e.g. studies by Hanaysha and Tahir [2016, p. 272], Akbar, Yousaf, Ul Haq and Hunjra [2011, p. 680], Wadhwa and Verghese [2015, p. 285], and Ugboro and Obeng [2000, p. 247]. In turn, Moura, Orgambídez-Ramos, and de Jesus [2015, p. 125] indicated that job satisfaction is strongly related to psychological empowerment and work engagement. Woon and Kahl [2015, p. 21] confirmed the positive relationship between employees' empowerment and their satisfaction. Similarly, the influence of empowerment upon organizational commitment was confirmed by Hanaysha [2016a, p. 298], Marzec [2014, p. 43], and Wadhwa and Verghese [2015, p. 285]. In addition, it was proven that psychological empowerment constitutes one of the main and critical factors reducing employees' turnover [Ertürk and Vurgun 2015, p. 34].

According to Kanter [as cited in: Yang et al. 2014, p. 186], empowerment is strongly related to work efficiency. Mehrabani and Shajari [2013, p. 60] verified the relationship between employees' empowerment and their effectiveness. In turn, Dizgah, Chegini, Farahbod and Kordabadi [2011, p. 973], indicated a relationship between employees' empowerment and organizational effectiveness. Dehghani, Gharooni and Arabzadeh [2014, pp. 1130-1141] observed a positive relationship between empowerment and entrepreneurship and organizational effectiveness. Hanaysha [2016b, p. 164] indicated a significant positive influence of employees' empowerment upon their productivity. Numerous studies indicate a close correlation between empowerment and general profits of the company [Blanchard 2007, p. 59]. Meyerson and Dewettinck [2012, p. 40] proved a significant difference between employees' performance before and after empowerment has been implemented.

Studies indicate that empowered employees manifest richer professional experience, are more active, have more energy, exhibit greater job satisfaction, and are more committed to the organization [Bass as cited in: Lan and Chong 2015, p. 185]. Özarallı [2015, p. 366] observed a positive impact of empowering leadership on employees' creativity. Similarly, Zhang and Bartol [2010, p. 107] proved that empowering leadership exerts a positive impact on psychological empowerment, which, in turn, boosts motivation and engagement in a creative process. Uzunbacak [2015, p. 997] indicated that the introduction of behavioral, psychological, social and structural empowerment influences the high level of innovation. 
Results of the introduction of empowerment are also beneficial for the organization's surrounding environment. Studies acknowledge the impact of empowerment in the organization on customer satisfaction, which was confirmed by Ugboro and Obeng [2000, p. 247], and on service quality, confirmed by Timothy and Abubakar [2013, p. 32].

\section{Conclusions}

Since the 1980s and the 1990s, empowerment has been attracting significant interest on the part of both practitioners and theoreticians. Its popularity results from challenges faced by modern organizations. Companies are forced to restrict their control, make their structures more flexible, react swiftly to changes emerging in their surroundings, and utilize knowledge and skills of their employees.

In order to include subordinates in decision-making and taking responsibility, it is necessary to view empowerment from the perspective of an individual - psychological empowerment, or from the standpoint of an organization - organizational empowerment.

Benefits for organizations resulting from the introduction of empowerment which were presented in the paper were verified in numerous worldwide studies encompassing several sectors and branches. Therefore, the subject matter of the paper is vital in the context of prospective studies, especially those pertaining to modern organizations.

\section{Bibliography}

Akbar, S.W., Yousaf, M., U1 Haq, N., Hunjra, A.I., Impact of Employee Empowerment on Job Satisfaction: An Empirical Analysis of Pakistani Service Industry, "Interdisciplinary Journal of Contemporary Research in Business" March 2011, vol. 2, no. 11.

Blanchard, K., Przywództwo wyższego stopnia, PWN, Warszawa 2007.

Chang, L.-C., Shih, C.-H., Lin, S.-M., The Mediating Role of Psychological Empowerment on Job Satisfaction and Organizational Commitment for School Health Nurses: A Cross-Sectional Questionnaire Survey, "International Journal of Nursing Studies" 2010, vol. 47, no. 4, http://dx.doi.org/10.1016/j.ijnurstu.2009.09.007

Chu, K.F., An Organizational Culture and the Empowerment for Change in SMEs in the Hong Kong Manufacturing Industry, "Journal of Materials Processing Technology" 2003, vol. 139, no. 1-3, http://doi.org/10.1016/S0924-0136(03)00527-2

Conger, J.A., Kanungo, R.N., The Empowerment Process: Integrating Theory and Practice, "The Academy of Management Review" 1988, vol. 13, no. 3.

Dehghani, S., Gharooni, A., Arabzadeh, A., Staff Empowerment, Entrepreneurial Behaviors and Organizational Efficiency in Iranian Headquarter Education, "Procedia - Social and Behavioral Sciences" 2014, vol. 109, https://doi.org/10.1016/j.sbspro.2013.12.600 
Dizgah, M.R., Chegini, M.G., Farahbod, F., Kordabadi, S.S., Employee Empowerment and Organizational Effectiveness in the Executive Organizations, "Journal of Basic and Applied Scientific Research" 2011, vol. 1, no. 9 .

Ebers, M., Maurer, I., Connections Count: How Relational Embeddedness and Relational Empowerment Foster Absorptive Capacity, "Research Policy" 2014, vol. 43, no. 2, http://doi.org/10.1016/j.respol.2013.10.017

Ertürk, A., Vurgun, L., Retention of IT Professionals: Examining the Influence of Empowerment, Social Exchange, and Trust, "Journal of Business Research" 2015, vol. 68, no. 1, http://doi.org/10.1016/j.jbusres.2014.05.010

Grajewski, P., Koncepcja struktury organizacji procesowej, TNOiK Dom Organizatora, Toruń 2003.

Hammuda, I., Dulaimi, M.F., The Theory and Application of Empowerment in Construction: A Comparative Study of the Different Approaches to Empowerment in Construction, Service and Manufacturing Industries, "International Journal of Project Management" 1997, vol. 15, no. 5.

Hanaysha, J., Examining the Effects of Employee Empowerment, Teamwork, and Employee Training on Organizational Commitment, "Procedia - Social and Behavioral Sciences" 2016a, vol. 229, https://doi. org/10.1016/j.sbspro.2016.07.140

Hanaysha, J., Testing the Effects of Employee Empowerment, Teamwork, and Employee Training on Employee Productivity in Higher Education Sector, "International Journal of Learning and Development" 2016b, vol. 6, no. 1, http://dx.doi.org/10.5296/ijld.v6i1.9200

Hanaysha, J., Tahir, P.R., Examining the Effects on Employee Empowerment, Teamwork, and Employee Training on Job Satisfaction, "Procedia - Social and Behavioral Sciences" 2016, vol. 219, https://doi.org/10.1016/j.sbspro.2016.05.016

Hocutt, M.A., Stone, T.H., The Impact of Employee Empowerment on the Quality of a Service Recovery Effort, "Journal of Quality Management" 1998, vol. 3, no. 1.

Jo, S.J., Park, S., Critical review on power in organization: empowerment in human resource development, "European Journal of Training and Development" 2016, vol. 40, no. 6, http://dx.doi.org/10.1108/EJTD-01-2016-0005

Karim, F., Rehman, O., Impact of Job Satisfaction, Perceived Organizational Justice and Employee Empowerment on Organizational Commitment in Semi-Government Organizations of Pakistan, "Journal of Business Studies Quarterly" 2012, vol. 3, no. 4.

Lan, X.M., Chong, W.Y., The Mediating Role of Psychological Empowerment between Transformational Leadership and Employee Work Attitudes, "Procedia - Social and Behavioral Sciences" 2015, vol. 172, https://doi.org/10.1016/j.sbspro.2015.01.353

Leach, D.J., Wall, T.D., Jackson, P.R., The Effect of Empowerment on Job Knowledge: An Empirical Test Involving Operators of Complex Technology, "Journal of Occupational and Organizational Psychology" March 2003, vol. 76, no. 1, https://doi.org/10.1348/096317903321208871

Marzec, I., Using Employee Empowerment to Encourage Organizational Commitment in the Public Sector, "Journal of Positive Management" 2014, vol. 5, no. 2, http://dx.doi.org/10.12775/JPM.2014.012

Mehrabani, S.E., Shajari, M., Relationship between Employee Empowerment and Employee Effectiveness, "Service Science and Management Research" December 2013, vol. 2, no. 4.

Meyerson, G., Dewettinck, B., Effect of Empowerment on Employees Performance, "Advanced Research in Economic and Management Sciences" July 2012, vol. 2.

Moura, D., Orgambídez-Ramos, A., de Jesus, S.N., Psychological Empowerment and Work Engagement as Predictors of Work Satisfaction: A Sample of Hotel Employees, "Journal of Spatial and Organizational Dynamics" 2015, vol. 3, no. 2.

Otto, J., Marketing relacji. Koncepcja i stosowanie, Wydawnictwo C.H. Beck, Warszawa 2004.

Özarallı, N., Linking Empowering Leader to Creativity: The Moderating Role of Psychological (Felt) Empowerment, "Procedia - Social and Behavioral Sciences" 2015, vol. 181, https://doi.org/10.1016/j.sbspro.2015.04.899

Potoczek, N., Empowering Employees in Process-Oriented Organizations, "Management Business Innovation" 2010, no. 6 . 
Quinn, R.E., Spreitzer, G.M., The Road of Empowerment: Seven Questions Every Leader Should Consider, "Organizational Dynamics" 1997, vol. 26, no. 2.

Robbins, T.L., Crino, M.D., Fredendall, L.D., An Integrative Model of the Empowerment Process, "Human Resource Management Review” 2002, vol. 12, no. 3, http://doi.org/10.1016/S1053-4822(02)00068-2

Sahoo, Ch.K., Das. S., Employee Empowerment: A Strategy towards Workplace Commitment, "European Journal of Business and Management" 2011, vol. 3, no. 11.

Spreitzer, G., Taking Stock: A Review of More Than Twenty Years of Research on Empowerment at Work, [in:] C. Cooper, J. Barling (eds.), Handbook of Organizational Behavior, Sage Publication, Thousand Oaks, CA 2007.

Timothy, A.T., Abubakar, H.S., Impact of Employee Empowerment on Service Quality - An Empirical Analysis of the Nigerian Banking Industry, "British Journal of Marketing Studies" 2013, vol. 1, no. 4.

Ugboro, I.O., Obeng, K., Top Management Leadership, Employee Empowerment, Job Satisfaction, and Customer Satisfaction in TQM Organizations: An Empirical Study, "Journal of Quality Management" 2000, vol. 5, no. 2, http://doi.org/10.1016/S1084-8568(01)00023-2

Uzunbacak, H.H., The Impacts of Employee Empowerment on Innovation: A Survey on Isparta And Burdur Organized Industrial Zones, “The Journal of International Social Research” 2015, vol. 8, no. 37, http://dx.doi.org/10.1016/j.ijnurstu.2007.12.006

Wadhwa, D.S., Verghese, M., Impact of Employee Empowerment on Job Satisfaction and Organizational Commitment: An Empirical Investigation with Special Reference to Selected Cement Industry in Chhattisgarh, "International Journal in Management and Social Science" 2015, vol. 3, no. 3, https://doi.org/10.1016/j.sbspro.2016.05.016

Whetten, D.A., Cameron, K.S., Developing Management Skills, Prentice Hall/Pearson, $8^{\text {th }}$ ed., Upper Saddle River, New Jersey 2011.

Wilkinson, A., Empowerment: Theory and Practice, "Personnel Review" February 1998, vol. 27, no. 1, http://dx.doi.org/10.1108/00483489810368549

Woon, L.P., Kahl, Ch., Employment Empowerment through Human Resource Department in Enriching Employee Satisfaction: The Hilton Way in Malaysia, "TEAM Journal of Hospitality \& Tourism" 2015, vol. 12, no. 1.

Yang, J., Liu, Y., Chen, Y., Pan, X., The Effect of Structural Empowerment and Organizational Commitment on Chinese Nurses Job Satisfaction, “Applied Nursing Research” 2014, vol. 27, no. 3, http://dx.doi.org/10.1016/j.apnr.2013.12.001.

Yukl, G., Leadership in Organizations, $7^{\text {th }}$ ed., Pearson, New Jersey 2007.

Zhang X., Bartol K.M., Linking Empowering Leadership and Employee Creativity: The Influence of Psychological Empowerment, Intrinsic Motivation, and Creative Process Engagement, "Academy of Management Journal” 2010, vol. 53, no. 1, http://dx.doi.org/10.5465/AMJ.2010.48037118

\section{Empowerment in Modern Organizations - Determinants and Benefits}

The objective of the paper is to present empowerment from various perspectives, indicate its determinants and applications in modern organizations. The paper is theoretical and informational in character. Empowerment revolving around the inclusion of employees in the decision-making process and development of their tangible influence upon the organization's operations constitutes an answer to needs of modern enterprises. The paper reviews definitions of empowerment, describes its elements from the point of view of employees and companies, and presents benefits and costs of empowerment incurred by the organization. A review of studies pertaining to the impact of empowerment on organizations was also conducted. 
Pobrane z czasopisma Annales $\mathrm{H}$ - Oeconomia http://oeconomia.annales.umcs.pl Data: 26/04/2023 10:59:36

\section{Uwarunkowania i korzyści empowermentu we współczesnych organizacjach}

Celem artykułu jest przedstawienie ujęcia empowermentu z różnych perspektyw, jego uwarunkowań i zastosowania we współczesnych organizacjach. Opracowanie ma charakter teoretyczno-poglądowy. Empowerment, polegający na włączeniu pracowników w proces podejmowania decyzji i rozwijania ich realnego wpływu na funkcjonowanie organizacji, stanowi odpowiedź na potrzeby współczesnego przedsiębiorstwa. W artykule dokonano przeglądu definicji empowermentu, opisano jego elementy z punktu widzenia pracownika i przedsiębiorstwa oraz przedstawiono korzyści i koszty empowermentu ponoszone przez organizację. Dokonano też przeglądu badań dotyczących wpływu empowermentu na organizację. 